\title{
Microbial IC50 Fold Change from Reference
}

National Cancer Institute

\section{Source}

National Cancer Institute. Microbial IC50 Fold Change from Reference. NCI Thesaurus.

Code C139119.

A fold change based on the concentration of a specific drug expected to produce 50

percent inhibition on the enzymatic activity of a microbial organism; it is a ratio calculated by the IC50 Subject Result divided by the IC50 Reference Control Result. 